\title{
Morphological description of Pentalcheles laevis postlarva collected from Suruga Bay, Japan (Crustacea, Decapoda, Polychelidae)
}

Kooichi Konishi, Munehiro Takami, Takashi Yanagimoto

\begin{abstract}
A morphological description is given for the postlarval specimen of the polychelid lobster, Pentacheles laevis, collected from Suruga Bay, on the Pacific coast of Japan. The specimen has been previously identified using the DNA barcoding method. Diagnostic larval characters distinguishing the previously known postlarvae in three genera, Pentacheles, Stereomastis, and Polycheles, are also noted.
\end{abstract}

Key words: Crustacea, Decapoda, Polychelidae, Pentacheles, Polycheles, Stereomastis, larval morphology

\section{Introduction}

The deep-sea blind lobsters of the family Polychelidae are of interest to marine zoologists not only for their unique appearance, such as having four or five pairs of chelate walking legs and a caridean-like triangular telson, but also for their evolutionary lineage: the polychelids are sometimes referred to as "living fossils" due to their relationship to the extinct eryonoid families of the Mesozoic era. The family Polychelidae consists of 40 extant species in six genera (Galil, 2000; Ahyong, 2009, 2012; Audo \& Furrer, 2020). Among these, 12 species in five genera have been recorded in Japan and its surrounding waters (Okada et al., 1966; Okutani, 1969; Galil, 2000; Kuramochi et al., 2004; Yamamoto \& Nagasawa, 2011; Komai \& Tsuchida, 2014). Despite the progress made in adult taxonomy and palaeontology of other decapod species, little is known about polychelid life history, particularly its larval stages.

Recently, we collected polychelid postlarvae from the Pacific coast of Japan, and one of the specimens from Suruga Bay was identified as Pentacheles laevis using DNA barcoding analyses (Yanagimoto et al., 2015, see Appendix).
The aim of the present paper is to describe the detailed morphology of $P$. laevis postlarva.

\section{Materials and Methods}

The polychelid postlarva was caught during research cruise of the $\mathrm{R} / \mathrm{V}$ Hokuto (Tokai University) in Suruga Bay $\left(34^{\circ} 56^{\prime} \mathrm{N} 138^{\circ} 38^{\prime} \mathrm{E}\right)$, on 14 May 2014, using a bottom larval net, at depths of 1304-1565 m. The observations and measurements of the postlarva were taken using an Olympus SZX10 stereomicroscope and a Nikon BX50 microscope equipped with a drawing tube. Carapace length (CL) was measured as the distance from the frontal margin to the posterior margin along the median line, and carapace width $(\mathrm{CW})$ as the greatest distance across the carapace excluding the lateral spines (see Figs.1A and 2B). The postlarva specimen used in the study was deposited at the Hokkaido University Museum under the accession No. ICHUM-6157.

Description of the postlarva of Pentacheles laevis Bate, 1878

Dimensions: $\mathrm{CL}=17.2 \mathrm{~mm}, \mathrm{CW}=16.8 \mathrm{~mm}$.

Color in life: Chephalothorax orange-red with 

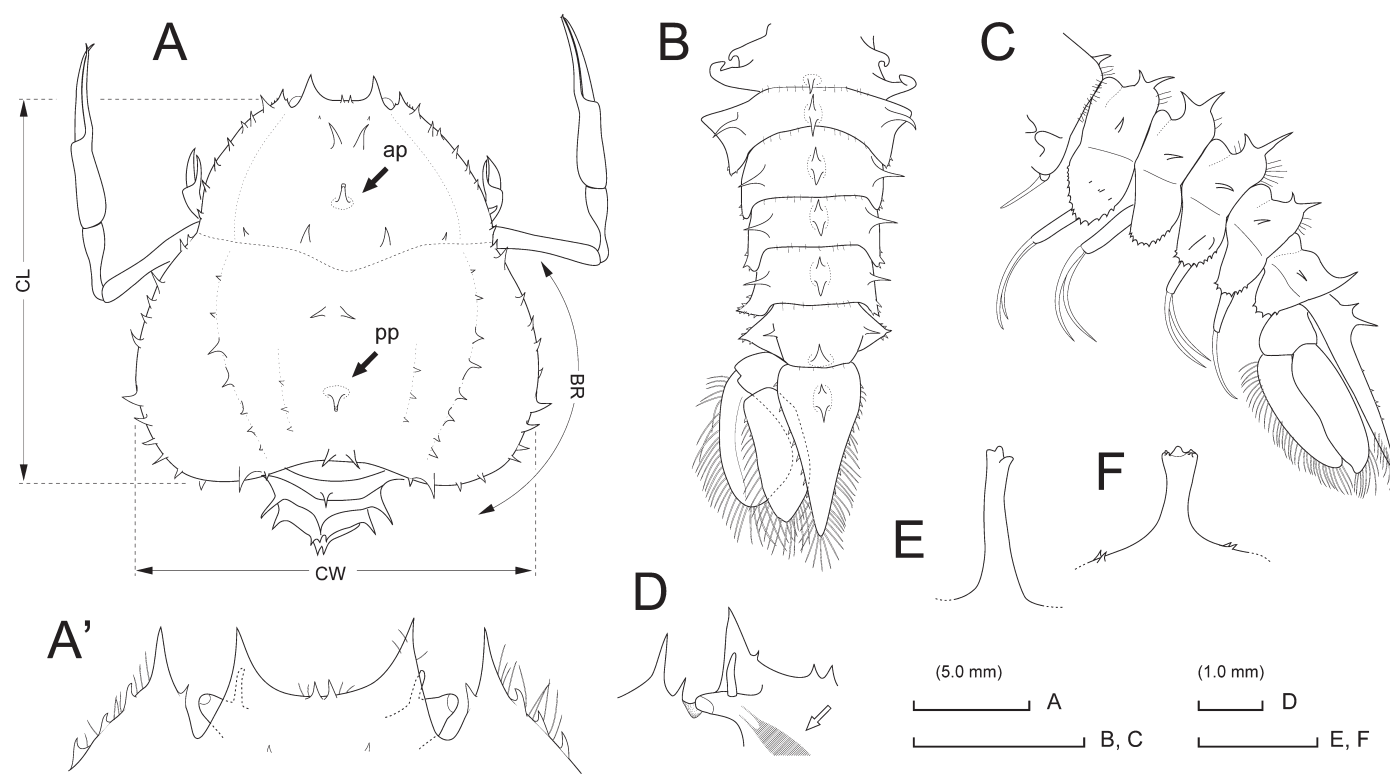

Fig. 1. Postlarva of Pentacheles laevis. A: whole body in dorsal view, A': frontal region of carapace (enlarged), B: pleon in dorsal view, C: pleon in lateral view, D: orbital region in ventral view, arrow indicating nerve cord, E: anterior pillar, F: posterior pillar. BR: branchial region, CL: carapace length, CW: carapace width, ap: anterior pillar, pp: posterior pillar.
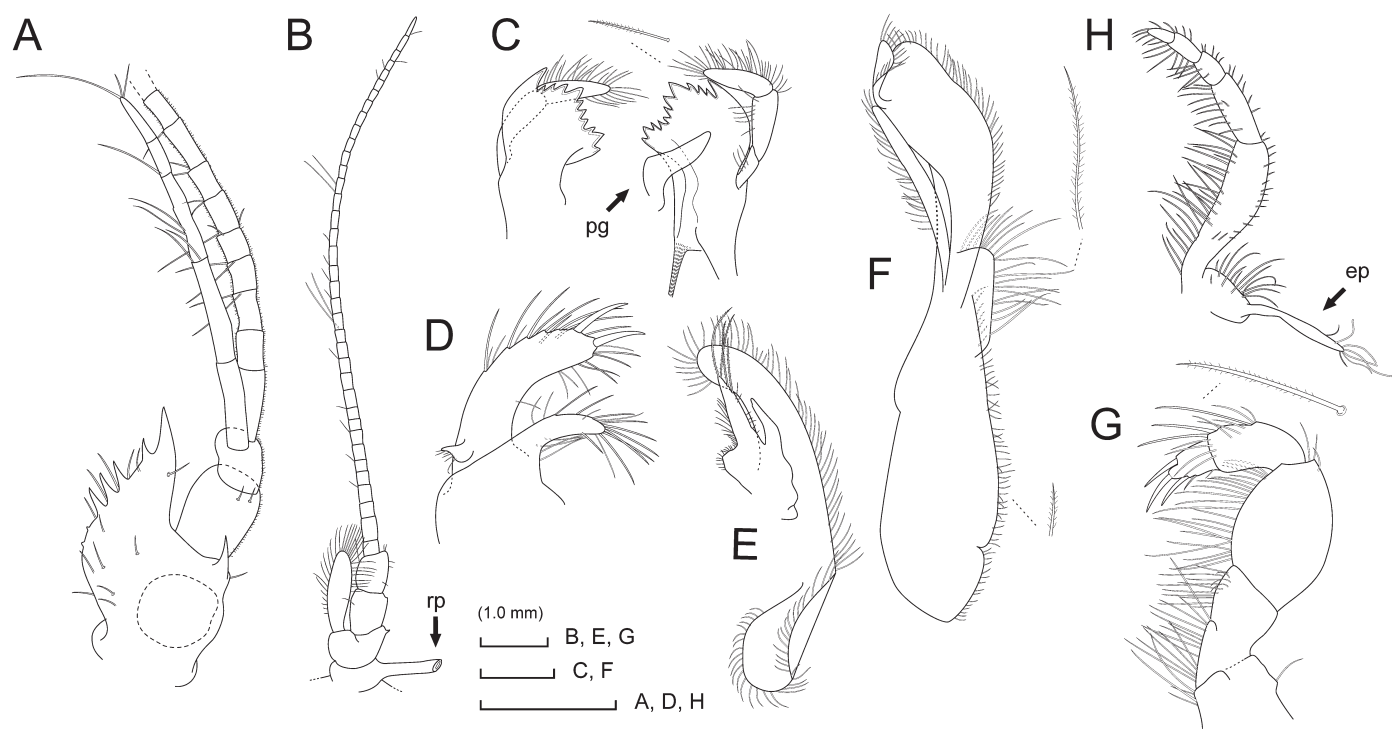

Fig. 2. Postlarva of Pentacheles laevis. A: antennule, B: antenna, $\mathrm{rp}=$ renal process, C: outer (left) and inner (right) sides of the left mandible, D: maxillule, E: maxilla, F: maxilliped 1, G: maxilliped 2, H: maxilliped 3. ep: epipod, pg: paragnath, rp: renal process. 


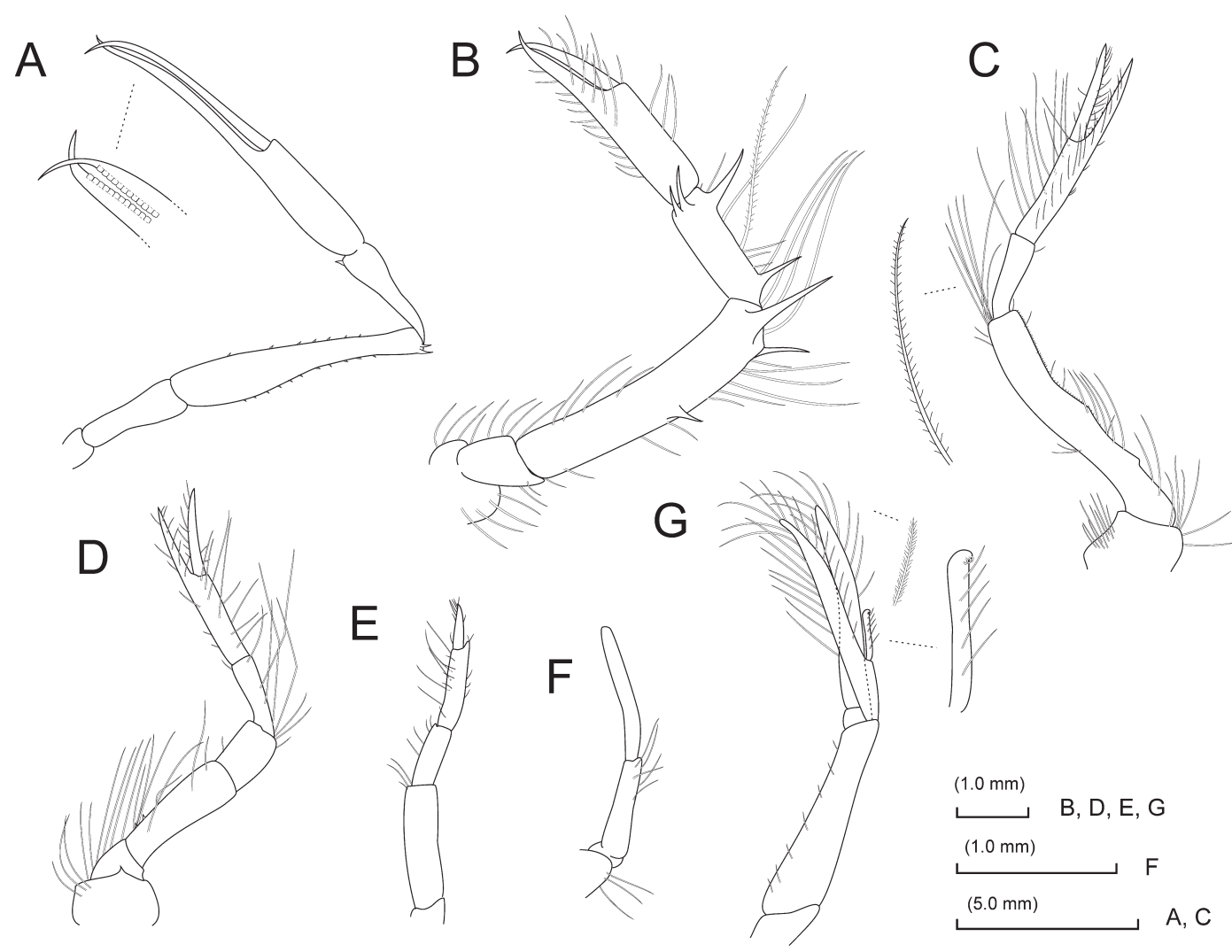

Fig. 3. Postlarva of Pentacheles laevis. A: pereiopod 1 (first cheliped), B: pereiopod 2, C: pereiopod 3, D: pereiopod 4, E: pereiopod 5, F: pleopod 1, G: pleopod 2.

parts of the pleonites and telson transparent with reddish spots.

Carapace (Figs. 1A-D): Globular and pearshaped in dorsal view, posterior margin slightly concave medially. CL slightly longer than CW. Posterolateral branchial region inflated. Spine arrangement on the middorsal line as " $2 \mathrm{r}, 2$, ap, 2,2 , pp, 2 ", from the rostral spine to the posterior margin [ap: anterior pillar (Fig. 1E), pp: posterior pillar (Fig. 1F), r: rostral]. Four carinae with spines on the branchial region. Orbital sinus V-shaped with an acute spine on its inner side. Eyestalk with a frontal blunt projection in front. Terminal of nerve cord visible near the eyestalk base through the integument (Fig. 1D, arrow).

Antennule (Fig. 2A): Biramous. Peduncle tree-segmented, basal segment flattened with one large and wide outer spine with outer margin bearing four spines, and one inner small spine. Exopod flagellum five-segmented, distal segment with three setae. Endopod flagellum multi-segmented with setae and numerous setules, approximately three times longer than outer flagellum.

Antenna (Fig. 2B): Biramous, coxal region with a long renal process (phymacerite), and basal region with a short anterolateral spine. Scaphocerite (exopod) forming spoon-shaped plate, with 29-31 marginal plumose setae. Endopod flagellum long, multi-segmented.

Mandible (Fig. 2C): No molar processes. Inner edge with 11 triangular teeth. Palp treesegmented with numerous setae. Paragnath small, forming digitiform plate.

Maxillule (Fig. 2D): Biramous, basial endite 
with two distal cuspidae and 20-22 marginal setae. Coxal endite with 18/20 setae. Endopod small, rudimentary lobe with six short setae distally.

Maxilla (Fig. 2E): Biramous. Coxal endite smaller than basial endite, with 19-21 setae. Basial endite with two stout spines and 20-22 setae. Endopod smaller than basial endite, unsegmented without setae. Scaphognathite large, elongate with numerous, marginal, plumose setae.

Maxilliped 1 (thoracopod 1) (Fig. 2F): Endopod with slender lobe. Exopodal lobe broad and elongate, anterior part bilobed.

Maxilliped 2 (thoracopod 2) (Fig. 2G): Endopod four-segmented, distal segment with three stout spines and two setae, and other segments with dense, long inner setae.

Maxilliped 3 (thoracopod 3) (Fig. 2H): Endopod five-segmented, with numerous long inner, and short outer setae. Coxal part with a long epipod fringed with 5-7 marginal setae.

Pereiopods (Fig. 3A-E): Pereiopod 1 chelate, largest, and more robust than the others. Inner margin of dactylus and propodus with minute cutting plates. Pereiopods 2-4 cheliform. Pereiopod 5 not chelate.

Pleon (Fig. 1B, C): Pleura of somite 1 with two lateral hook-like spines with rounded ends and one dorsal spine on the mid-posterior margin. Pleonite 2-5 with rounded triangular pleura with serrate margins; median carina bispinose, anterior spine larger than posterior one, and a pair of lateral spines.

Pleopods (Fig. 3F, G): Uniramous in pleonite 1. Biramous in pleonite 2-6; endopod with 20 23 plumose setae and an appendix interna bearing three cincinnuli on its distal end; exopod with 10-15 plumose setae.

Uropod (pleonite 6 pleopod): Endopod and exopod with numerous long plumose setae marginally.

Telson: Subtriangular with a bispinose middorsal carina, lateral margin with 8-9 spines and numerous long setae.

\section{Discussion}

The developmental phase of the present specimen is classified as postlarval because it lacks a maxillipedal exopod with natatory setae and has functional pleopods. At present, however, a more accurate stage of the larval phase (i.e., the first postlarva (megalopa, decapodid) or subsequent postlarval stages) is not clear due to the lack of the morphological information on successive postlarval developments observed under the laboratory-rearing.

The comparison among selected morphological characters of different species of polychelid postlarvae, except for the so-called 'Eryoneicus species', is shown in Table 1. Boyko (2006) examined the polychelid adult and larval specimens at the Yale Peabody Museum Collections, and morphologically identified the postlarvae up to the species level. He identified the larvae to $P$. laevis and Stereomastis talismani (as Polycheles talismani), although he gave no detailed morphological description of the larval specimens. In his paper, the postlarva of $P$. laevis was distinguished from that of $S$. talismani in four characters as follows: 1) two small rostral spines, 2) the antennal basal segment bear a single anterolateral spine, 3) inflated branchial regions of the carapace, and 4) a well-developed epipod on the maxilliped 3. However, the larval morphology of Stereomastis warrants re-examination as parentage has not been established by either larval rearing or DNA analyses. The basal antennal segment with double spines (Boyko, 2006), a diagnostic character of Polycheles and Stereomastis are not recognized by the other authors (Calman, 1925; Quintana \& Retamal, 1984; Torres et al., 2010). The middorsal spination observed in the present specimen differs from that of previously reported by having fewer spines, especially anterior to the anterior pillar. It may be possible that the spination decreases in successive stages of postlarval development. There is a dearth of morphological data on polychelid larvae 
Table 1. Comparison of selected characters in polychelid postlarvae.

\begin{tabular}{|c|c|c|c|c|c|c|c|}
\hline \multirow{2}{*}{\multicolumn{2}{|c|}{$\begin{array}{l}\text { Genus } \\
\text { Species }\end{array}$}} & Polycheles & \multicolumn{3}{|c|}{ Stereomastis } & \multicolumn{2}{|c|}{ Pentacheles } \\
\hline & & Po. typhlops & S. talismani ${ }^{\dagger}$ & S. suhmi & S. pacifica & Pe. laevis & Pe. laevis \\
\hline \multicolumn{2}{|c|}{ Source of materials } & $P+L+D$ & $P$ & $\mathrm{P}$ & $\mathrm{P}$ & $P$ & $P+D$ \\
\hline \multicolumn{2}{|c|}{ References ${ }^{\dagger+}$} & 1) & 2) & 3) & 4) & 2) & Present study \\
\hline \multirow[t]{5}{*}{ Carapace } & CL (mm) & 8.5 & $21^{\pi+\pi}$ & $(26)^{\dagger+t i}$ & 12 & $23^{\dagger \dagger}$ & 17.2 \\
\hline & CL-CW lengths & $\mathrm{CL}>\mathrm{CW}$ & $\mathrm{CL}>\mathrm{CW}$ & $\mathrm{CL}>\mathrm{CW}$ & $\mathrm{CL}>\mathrm{CW}$ & $\mathrm{CL} \geq \mathrm{CW}$ & $\mathrm{CL} \geq \mathrm{CW}$ \\
\hline & Branchial region & Not inflated & Not inflated & Not inflated & Not inflated & Inflated & Inflated \\
\hline & Rostral spine & 1 & 1 & 2 & 1 & 2 & 2 \\
\hline & $\begin{array}{l}\text { Middorsal } \\
\text { spination }\end{array}$ & $\begin{array}{l}1 \mathrm{r}, 1,1,1,2, \mathrm{p} \\
2,2, \mathrm{p}, 2\end{array}$ & ND & $\begin{array}{l}2 \mathrm{r}, 1,1,2,2, \mathrm{p} \\
2,2,2, \mathrm{p}, 2\end{array}$ & $\begin{array}{l}1 \mathrm{r}, 2,1, \mathrm{p}, 2,2, \\
1,2\end{array}$ & ND & $\begin{array}{l}2 r, 2, p, 2,2, p, \\
2\end{array}$ \\
\hline Eye stalk & Frontal spine & Acute end & ND & Blunt end & ND & ND & Blunt end \\
\hline Maxilliped 3 & Epipod & Reduced & ND & Reduced & Reduced & Developed & Developed \\
\hline
\end{tabular}

CL: carapace length, CW: carapace width, D: DNA analysis, L: laboratory-reared, ND: no data, P: plankton collection, p: pillar, r: rostral.

${ }^{\dagger}$ as Polycheles talismani. ${ }^{\dagger}$ 1) Torres et al. (2010), 2) Boyko (2006), 3) Calman (1925), 4) Quintana \& Retamal (1984).

measured from the figures. ${ }^{\dagger+1}$ total length.

such that a discussion on development of middorsal spination is premature. The other four genera i.e., Cardus, Homeryon, Stereomastis, and Willemoesia virtually unknown. The comparison of polychelid postlarvae (Table 1) is only preliminary at present. Nonetheless, we propose an additional character in distinguishing postlarvae in the previously known three genera: i.e., the eyestalk spine either having a long blunt or a short acute end. Thus, postlarvae of Pentacheles differs from those of Polycheles and Stereomastis in having inflated branchial carapace region and well-developed epipod on maxilliped 3, while postlarvae of Polycheles differs from those of Pentacheles and Stereomastis in having an acute-ended spine on eyestalk.

Since Bate's (1882) description, under the name of 'Eryonoeicus,' which was believed to be a pelagic decapod genus, until Sund (1915) revealed their parentage, and the increased interest of planktologists due to its large body size and unique appearance (Martin, 2014), a few larval forms of the species have been described (e.g. Bernard, 1953). These larval descriptions were done independently from adult classification creating the "Eryonoeicus problem." As a result, this rather generic name was suppressed in 1964 by the International
Commission on Zoological Nomenclature (ICZN, 1964; Boyko, 2006). To date, parentages in the polychelid larvae have been confirmed in only one species, Polycheles typhlops by laboratory-rearing and DNA analyses (Guerao \& Abelló, 1996; Torres, et al., 2014). Williamson (1983) reported on the hatching of $P$. laevis (as Polycheles granulatus) prezoea, but he gave no morphological description and rearing data. The present larval description is the second one of which parentage is confirmed in polychelid larvae.

In addition to the extant polychelids, it is noteworthy about recent progress in larval studies on extinct decapod crustaceans. Discoveries of fossil polychelid larvae from the Mesozoic era show different larval forms and developmental patterns of spination from those of the extant species (Haug et al., 2015; Eiler \& Haug, 2016). Larval morphological study of polychelids is therefore indispensable for understanding of the history of larval evolution in decapod crustaceans.

\section{Acknowledgments}

We thank the crew of R/V Hokuto of Tokai University for collecting samples. Our thanks are also due to the editor and reviewers for 
their valuable suggestions and comments.

\section{$\square$ Literature Cited}

Ahyong, S. T., 2009. The polychelidan lobsters: phylogeny and systematics (Polychelida: Polychelidae). In: Martin, J. W., Crandall, K. A. \& Felder, D. L. (eds.) Decapod Crustacean Phylogenetics. Crustacean Issues 18, pp. 369-396.

Ahyong, S. T., 2012. Polychelid lobsters (Decapoda: Polychelida: Polychelidae) collected by the CIDARIS expeditions off Central Queensland, with a summary of Australian and New Zealand distributions. Memoirs of the Queensland Museum, 56: 1-7.

Audo, D. \& Furrer, H., 2020. A new polychelidan lobster from the Alpine Lower Jurassic of southeastern Switzerland. Neues Jahrbuch für Geologie und Paläontologie, 296: 29-40.

Bernard, F. R., 1953. Decapoda Eryonidae (Eryoneicus et Willemoesia). Dana Report, No. 37, 93 pp.

Bate, C. S., 1882. Eryoneicus, a new genus allied to Willemoesia. Annals and Magazine of Natural History, Ser. 5, 10: 456-458.

Boyko, C., 2006. New and historical records of polychelid lobsters (Crustacea: Decapoda: Polychelidae) from the Yale Peabody Museum collections. Bulletin of the Peabody Museum of Natural History, 47: 37-46.

Calman, W. T., 1925. On macrurous decapod Crustacea collected in South African waters by the S.S. "Pickle". Reports of the Fisheries and Marine Biological Surveys of South Africa, 4: 1-26.

Eiler S. M., \& Haug J. T., 2016. Larval development of fossil polychelidan crustaceans, exemplified by the 150 million years old species Palaeopentacheles roettenbacheri. Neues Jahrbuch für Geologie und Paläontologie Abhandlungen, 279: 295-310.

Galil, B. S., 2000. Crustacea Decapoda: review of the genera and species of the family Polychelidae Wood-Mason, 1874. In: Crosnier, A. (ed) Résultats des Campagnes MUSOR-
STOM, vol 21. Mémoires du Muséum National d'Histoire naturelle, 184: 285-387.

Guerao, G., \& Abelló, P., 1996. Description of the first larval stage of Polycheles typhlops (Decapoda: Eryonidea: Polychelidae). Journal of Natural History, 30: 1179-1184.

Haug, J. T., Audo, D., Haug, C., Saad, P.A., Petit, G. \& Charbonnier, S., 2015. Unique occurrence of polychelidan lobster larvae in the fossil record and its evolutionary implications. Gondwana Research, 28: 869-874.

ICZN, 1964. Opinion 702. Bulletin of Zoological Nomenclature, 21:111-112.

Komai, T., \& Tsuchida, S., 2014. Deep-Sea decapod crustaceans (Caridea, Polychelida, Anomura and Brachyura) collected from the Nikko Seamounts, Mariana Arc, using a remotely operated vehicle "Hyper-Dolphin". Zootaxa, 3764: 279-316.

Kuramochi, T., Sudou, Y., Ogawa, M., Tamaki, E. \& Naganuma, T., 2004. Record of Polycheles enthrix (Decapoda: Polychelidae) from offKume Island, Ryukyu Islands, southwestern Japan. Journal of the Graduate School Biosphere Science, Hiroshima University, 43: 1-6. [In Japanese]

Martin, J. W., 2014. Polychelidea. Pp. 279-282. In: Martin, J. W., Olsen, J., \& Høeg, J. T. (eds.) Atlas of crustacean larvae. The Johns Hopkins University Press, Baltimore, 370 pp.

Okada, Y., Sakamoto, I., Amano, R. \& Tominaga, Y., 1966. Preliminary report of the benthic biological survey in Suruga Bay. Journal of the Faculty of Oceanography, Tokai University, 1: 135-155.

Okutani, T., 1969. Synopsis of bathyal and abyssal megalo-invertebretes from Sagami Bay and the south off Boso Peninsula trawled by the R/V Soyo-Maru. Bulletin of the Tokai Regional Fisheries Research Laboratory, 57: $1-62$.

Quintana, R., \& Retamal, M. A., 1984. Two pelagic stages of Stereomastis pacifica (Faxon) collected in the Chile-Peru Trench (Polychelidae: Macrura). Researches on Crustacea, 13/14: 133-142. 
Sund, O., 1915. Eryonicus - Polycheles. Nature, 95: 372.

Torres, A. P., Palero, F., Dos Santos, A., Blanco, P. A. E., \& Guerao, A. B. G., 2014. Larval stages of the deep-sea lobster Polycheles typhlops (Decapoda, Polychelida) identified by DNA analysis: morphology, systematic, distribution and ecology. Helgoland Marine Research, 68: 379-397.

Williamson, D. I., 1983. Crustacea Decapoda: larvae. VIII. Nephropidea, Palinuridea, and Eryonidea. Fiches D'Identification du Zooplancton, 167/168, Copenhagen: Conseil International pour l'Exploration de la Mer. 8 pp.

Yamamoto, K., \& Nagasawa, K., 2011. Shrimps and lobsters from the continental slope of the East China Sea. Bulletin of the Biogeographical Society of Japan, 66: 27-39. (In Japanese with English summary)

Yanagimoto, T., Konishi, K., Takami, M. \& Saruwatari, T., 2015. Species identification of polychelid postlarvae collected from the Pacific coast of Honshu, Japan using DNA analyses. Cancer, 24: 7-13. (In Japanese with English summary)

\section{Addresses}

(KK) (TY) Fisheries Resources Institute, Japan Fisheries Research and Education Agency, 2-12-4 Fukuura, Kanazawa-ku, Yokohama, Kanagawa 236-8648, Japan

(MT) Tokai University, School of Marine Science and Technology, 3-20-1 Orido, Shimizu, Shizuoka, 424-8610 Japan

\section{E-mail address of corresponding author} (KK)kzoea@fra.affrc.go.jp

\section{Appendix-Summary of DNA barcoding methods in our previous work}

Muscle samples from the postlarval pleon to be used in PCR amplification of the COI and ITS1 gene were extracted using QuickGene-810 ${ }^{1)}$. The amplification was done using the universal primers LCO1490 and HCO2198. The PCR reactions were carried out in a volume of $10 \mu \mathrm{L}$ containing $20-50 \mathrm{ng}$ template DNA, $1 \mu \mathrm{L}$ of $10 \times$ PCR buffer, $0.8 \mu \mathrm{L}$ of dNTP $(2.5 \mathrm{mM}), 1 \mu \mathrm{L}$ of each primer $(10 \mu \mathrm{M})$, $0.05 \mu \mathrm{L}$ of $5 \mathrm{U} / \mu \mathrm{L}$ Ex Taq Polymerase Hot Start Version ${ }^{2)}$ in a Model 9700 Thermal Cy$\mathrm{cler}^{3)}$. The amplified products were electrophoresed on a $1.5 \%$ agarose gel, and stained with EtBr. The remnants of the primers and dNTP were removed by treatment of the amplicons with ExoSAP-IT ${ }^{4)}$ after which they were subjected to direct sequencing using the PCR primers. DNA for cycle sequencing reactions were carried out using a BigDye Terminator Ver3.1 $\mathrm{kit}^{3)}$, and sequencing was conducted on an ABI3730XL Automatic Sequencer ${ }^{3)}$ with forward and reverse primers. The primers used for sequencing were the same as those for PCR amplification. The ITS1 region was amplified with primers $\mathrm{MD}-1$ and $5.8 \mathrm{SH}$. PCR products with ITS sequences were cloned into electrocompetent $E$. coli using a TOPO TA cloning $\mathrm{kit}^{5}$. Eight white colonies were randomly selected, then amplified by PCR were conducted using primers of M13 and its reverse primers. The resultant sequences were edited and aligned using ATGC software ${ }^{6}$. The determination of Kimura's 2 parameter (K2P) genetic distance, and construction of the phylogenetic tree were performed using MEGA 5.05 software.

The nucleotide sequences data of the postlarva were entered into a DNA Database under accession numbers of LC022125 for the ITS1 region and LC022130 for the COI.

1) Wako, 2) TAKARA, 3) Applied Biosystems, 4) GE Healthcare, 5) Invitrogen, 6) GENETYX. 